\title{
ASSESSMENT OF AGING OF CORK AND TISAF MATERIALS IN THE SAFKEG 3940A PACKAGE IN KAMS (U)
}

\author{
Philip R. Vormelker and Andrew J. Duncan \\ Savannah River Technology Center \\ Strategic Materials Technology Department \\ Materials Technology Section
}

Publication Date: June 2003

\footnotetext{
Westinghouse Savannah River Company

Savannah River Site

Aiken, SC 29808

This document was prepared in connection with work done under Contract No. DE-AC09-96SR18500

with the U. S. Department of Energy
} 
This document was prepared in conjunction with work accomplished under Contract No. DE-AC09-96SR18500 with the U. S. Department of Energy.

\section{DISCLAIMER}

This report was prepared as an account of work sponsored by an agency of the United States Government. Neither the United States Government nor any agency thereof, nor any of their employees, makes any warranty, express or implied, or assumes any legal liability or responsibility for the accuracy, completeness, or usefulness of any information, apparatus, product or process disclosed, or represents that its use would not infringe privately owned rights. Reference herein to any specific commercial product, process or service by trade name, trademark, manufacturer, or otherwise does not necessarily constitute or imply its endorsement, recommendation, or favoring by the United States Government or any agency thereof. The views and opinions of authors expressed herein do not necessarily state or reflect those of the United States Government or any agency thereof.

This report has been reproduced directly from the best available copy.

Available for sale to the public, in paper, from: U.S. Department of Commerce, National Technical Information Service, 5285 Port Royal Road, Springfield, VA 22161, phone: (800) 553-6847, fax: (703) 605-6900

email: orders@ntis.fedworld.gov

online ordering: http://www.ntis.gov/help/index.asp

Available electronically at http://www.osti.gov/bridge

Available for a processing fee to U.S. Department of Energy and its contractors, in paper, from: U.S. Department of Energy, Office of Scientific and Technical Information, P.O. Box 62, Oak Ridge, TN 37831-0062,

phone: (865)576-8401,

fax: (865)576-5728

email: $\underline{\text { reports@ adonis.osti.gov }}$ 


\section{LIST OF FIGURES}

Figure 1. Overall Schematic of the SAFKEG 3940A Packaging Assembly ............................ 7

Figure 2. Exterior sections (top, middle, and bottom) of TISAF taken from a SAFKEG package.

Figure 3. Exterior sections (top, middle, and bottom) of TISAF taken from a SAFKEG package.

Figure 4. Outer surface of middle section of TISAF .......................................................... 10

Figure 5. Inner surface of bottom section of TISAF from Figure $3 \ldots \ldots \ldots \ldots \ldots \ldots \ldots \ldots \ldots \ldots \ldots \ldots \ldots \ldots . . .11$

Figure 6. Photo of broken section of TISAF revealing wide range of cell sizes......................11

Figure 7. Circled areas in Image reveals porosity on the ridge formed by the outer keg.......... 12

Figure 8. In top TISAF section, near the top surface, porosity is visible ................................. 12

Figure 9. Room Temperature Compression Test Data for Resin-Bonded Cork ${ }^{1}$....................... 13

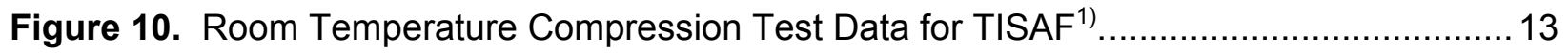

Figure 11. Room Temperature Tensile Test Data of Resin Bonded Cork. .............................14

Figure 12. Room Temperature Uni-axial Compression Data of Resin Bonded Cork................ 14

Figure 13. Room Temperature Hydrostatic Compression Data for Resin Bonded Cork ............ 15

Figure 14. Room Temperature Tensile Test Data of TISAF. ............................................... 15

Figure 15. Room Temperature Test Data for TISAF in Compression, Tension and Tri-axial

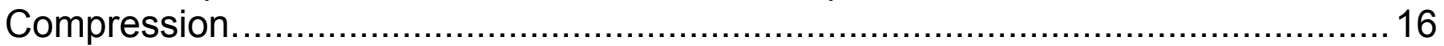

Figure 16. Room Temperature Compression Test of TISAF. .................................................16

Figure 17. Selected Stress Strain Curves used for the Mohr's Circle representation of Fracture Stress vs. Shear Stress for TISAF.................................................................... 17

Figure 18. Mohr's Circle representation of Fracture Stress vs. Shear Stress for TISAF........... 17

Figure 19. Weight loss from TGA Analysis of Resin Bonded Cork in Flowing Argon and Air.... 18

Figure 20. Weight loss from TGA Analysis of TISAF in Flowing Argon.................................. 18 


\section{LIST OF ABBREVIATIONS}

$\begin{array}{ll}\text { ASTM } & \text { American Society for Testing and Materials } \\ \text { ASME } & \text { American Society of Mechanical Engineers } \\ \text { PCV } & \text { Primary Container Vessel } \\ \text { RFETS } & \text { Rocky Flats Environmental Technology Site } \\ \text { SARP } & \text { Safety Analysis Report for Packaging } \\ \text { SRS } & \text { Savannah River Site } \\ \text { SRTC } & \text { Savannah River Technology Center } \\ \text { SCV } & \text { Secondary Container Vessel } \\ \text { SS } & \text { Stainless Steel }\end{array}$





\subsection{SUMMARY}

This report provides an assessment of the potential for aging and degradation of the resinbonded cork and the Thermal-Insulating, Shock-Absorbing Foam (TISAF) materials that are components of the SAFKEG 3940A package ${ }^{1)}$. This package may be used for interim storage of plutonium materials in the Savannah River Site K-Area Materials Storage (KAMS). These materials are important to the performance of the SAFKEG package in KAMS in several areas as follows:

- The mechanical properties of the cork and foam are inputs to the structural analyses of the SAFKEG 3940A package that include the KAMS design basis events. Mechanical testing (compression and tensile) of the cork and foam was performed to develop a set of baseline (non-aged condition) properties, supplementing the properties reported in the Safety Analysis Report for the 3940A SAFKEG Package. These properties were developed for input to structural analyses of the SAFKEG 3940A package under KAMS accident events. The testing details and results are contained in this report.

- The composition and compatibility of the cork and foam materials with the other components of the package under aging conditions are needed to establish and maintain containment and handleability of the package. Various tests were performed to provide materials data to evaluate the potential for corrosion of the stainless steel outer containment vessel and the keg due to contact with cork and foam materials. Samples of cork and foam were examined to determine their potential to absorb and contain water. Both the cork and foam readily absorb water due to their open cell structures that could lead to conditions aggressive to the stainless steel materials. In the case of the TISAF, the $\mathrm{pH}$ of the water was lowered from approximately 7 to approximately 2. High levels of chloride (approximately $5000 \mathrm{ppm}$ ) in the cork were measured by neutron activation. This level of chloride would cause pitting attack of stainless steel if chloride was leached from the cork and sufficient water was present. This condition is not expected in KAMS.

- The physical properties of the cork and foam are inputs to the thermal analysis. The physical behavior under aging conditions is important to the potential off-gassing and dimensional changes. The properties reported in the Safety Analysis Report for the 3940A SAFKEG Package were used in the thermal analyses of the SAFKEG in KAMS. Thermo-gravimetric analysis (TGA) was used to examine the possibilities of chemical and density changes as a result of aging. Both materials (as-received condition) appeared to release water at the temperatures expected during storage conditions but were otherwise stable.

The conclusions support the use of the SAFKEG 3940A package for interim use for containment in KAMS for a period of 10+ years. The conclusions are predicated on the surveillance of the materials to verify that degradation significant to the performance of the 3940A package to provide containment is not occurring.

\subsection{BACKGROUND AND MATERIALS DESCRIPTION}

Plutonium-bearing materials (metal and oxides) currently stored at the Rocky Flats Environmental Technology Site (RFETS) and at the Hanford Site (Richland - RL) are to be placed in 3013 storage containers ${ }^{2}$. The 3013 containers from RFETS are being loaded in 9975 shipping packages, and are planned to be shipped to SRS shortly. The 3013 containers from RL may be shipped to SRS in SAFKEG 3940A shipping packages ${ }^{1)}$ (Figure 1). The interim storage facility for the packages at the Savannah River Site, K-Area Materials Storage 
(KAMS), is being readied to safely receive and store these packages for interim storage prior to future disposition. The SAFKEG 3940A shipping package design consists of a double skinned stainless steel keg body (outer keg is 304 stainless steel (SS) with a 304L liner) with a bolted closure lid and O-ring seal (Figure 1). The cavity between the keg and the liner is filled with a layer of phenolic foam, also known as TISAF (Thermal-Insulating, Shock-Absorbing Foam). This cavity is normally sealed but will vent through a bottom vent plug during a fire accident condition. Within the liner is a resin-bonded cork layer; two removable 304L stainless steel containment vessels, each sealed with a bolted lid and double O-rings as shown in Figure 1. The 3013 storage container is placed inside the inner containment vessel (ICV) that is inserted into the outer containment vessel (OCV).

The TISAF foam is used as an insulator and held in a sealed annular space between two layers of stainless steel in the SAFKEG 3940A. The TISAF material is manufactured by a proprietary process and formulation and is based on a phenolic resin (chemical formula $\mathrm{C}_{7.4} \mathrm{H}_{7.8} \mathrm{O}$ ) filled with an unknown amount of calcium sulfate semi-hydrate (plaster of paris) which subsequently hydrates to form calcium sulfate dihydrate, or gypsum $\left(\mathrm{CaSO}_{4} \cdot 2 \mathrm{H}_{2} \mathrm{O}\right)$. The foam composition includes the following; $39.4 \%$ carbon, $31.9 \%$ oxygen, $13.8 \%$ calcium, $11 \%$ sulfur, and $3.8 \%$ hydrogen. There are also small amounts of phosphorus and no chlorides are in the foam. The foam is produced by reacting the phenolic resin and filler with paratoluene sulphonic acid (3\%) and ortho-phosphoric acid (0.6\%). All percentages are based on weight. ${ }^{3)}$ The acid is stated to completely react in the foaming process. During the foaming process, the foam adheres to the stainless steel. $^{4)}$

In the 1970's and 1980's the roofing and chemical industries suffered bad publicity and replacement costs due to extensive corrosion of roof decking and piping from moisture absorption by foam insulation with subsequent acid and chloride release causing corrosion on steel. $^{5)-6)}$ Specific corrosion problems with steel were noted with phenolic foam insulation. ${ }^{7 \text { ) }}$

Due to the historical problem with thermal insulation, tests were conducted on TISAF to determine moisture effects and chloride content. A reduced size TISAF sample was immersed in water for 96 hours per ASTM D-2842. ${ }^{8)}$ The single test result revealed $46 \%$ water absorption. The TISAF exhibited a constant release of bubbles. Because of the gypsum content and the cell nature of this foam, the high water absorption in the structure is thought to be the result of interconnecting paths between individual cells which allows air to be released as exhibited by the bubbles.

Samples of the TISAF from a SAFKEG package are shown in the photographs in Figures 2-8. Open cells (or porosity) are visible on both sides of the TISAF. TISAF has a wide distribution of cell sizes, on the inside surface and the outside, as seen in Figures 4-8. A distribution in cell sizes was also observed from top to bottom and from surface to center thickness. This could indicate anisotropy and properties may be different depending on parallel to or transverse to the pouring direction. The SAFKEG manufacturer states that the TISAF adheres to the stainless steel surfaces after curing.

Initial testing of the TISAF revealed a significant $\mathrm{pH}$ reduction (from 7.0 to 2.2 after approximately 6 hours, and leveled out at 2.31 after 96 hours of water immersion ${ }^{9}$. As long as the seal is maintained, only minimal entrained moisture would be expected in the TISAF and this would not be sufficient to cause a low pH leachate in the compartment containing the TISAF. Neutron activation analysis was used to measure the chloride level in the foam. The 
results showed the level is $49+/-8 \mathrm{ppm}$. This level of chloride is typically not significant to cause pitting corrosion attack for materials in contact with stainless steel.

Cork is a natural wood product produced in granular form. The cork in the SAFKEG 3940A is mixed with a synthetic resin binder. The mixture of the two is then compressed with heat to form the required shape. The synthetic resin is a polyurethane resin. A sealer is also used and it is a two-part compound based on urea formaldehyde with an alkyd plasticizer made by Rustins Ltd. ${ }^{1)}$ coating. The outside surface of the cork is then sealed with an organic polymer. The resin and organic polymer should seal the cork. In addition, the cork is preserved in the SAFKEG with an O-ring on the keg to provide for weather protection. Hence, it is unlikely that moisture (other than any on the interior during loading) will ever be a corrosion problem between the cork and the stainless steel liner and outer containment vessel. However, the statement in the SAFKEG 2863 SARP states that the O-ring seal is only designed for weather protection and is not designed to be airtight. ${ }^{10)}$ Since high humidity air infiltration in the SAFKEG 3940A lid is possible, and water immersion tests were not conducted prior to the present study, a preliminary immersion tests was conducted on the cork. Using the same tests methods mentioned above for TISAF, the cork water immersion results revealed that $51 \%$ water was absorbed with a $19 \%$ increase in volume and the $\mathrm{pH}$ level ended up as 6.3 . Both tests were carried out for 96 hours. Water absorption in a cork that has a resin binder should not occur if sufficient resin was used to coat individual granules. This shows that if moisture were to penetrate into the cork from condensation (or high humidity levels), swelling would occur and could hold moisture against the stainless steel. Chloride levels in the cork were determined to be $4890+/-65$ ppm. This level of chloride would cause pitting of the stainless steel if the chloride was leached from the cork and sufficient water was present. This is a potential problem and is an important item to monitor as part of surveillance in storage.

One potential problem in the long-term storage of the SAFKEG 3940A is the unknown behavior of the TISAF and the cork at the temperature conditions in the package and how aging affects their insulation and impact absorbing properties. In general, there is little documented information describing time- and temperature-induced changes in mechanical and physical properties for any foam or cork materials. One report will be described below.

Aging properties of the TISF and cork are not provided in the SARP. ${ }^{1)}$ Corrosion Assessment and aging of stainless steel components used in the 3013 storage container are currently under evaluation. ${ }^{11)}$ Normal properties of materials that are affected by aging include physical properties such as tensile strength, compressive strength, impact strength, modulus, dimensions and weight changes. The TISAF is entirely contained within the annular space between two stainless steel walls and access to air is expected to be minimal. The only available air is that contained within the closed cell walls of the foam during the insertion process. Moisture should not be a problem as long as the TISAF annular space is sealed. The seal is maintained by the bottom seal plug in the SAFKEG 3940A design, Figure 1.

\subsection{MECHANICAL PROPERTIES}

Mechanical testing was performed to establish a set of baseline materials properties for the determination of the impact of aging and to serve as inputs for stress analyses of hypothetical accident scenarios. The tests complemented the data already available in the SARP and provided a starting point by which the effects of aging can be determined. In the SARP the effect of temperature on the relationship between stress and strain is well represented. Figures 9 and 10 show how the stress vs. strain curve changes with temperature for resin bonded cork 
and TISAF, respectively. However, the effects of strain rate and loading conditions are available. To supplement the data available, tension, compression and multi-axial compression tests were performed on both cork and TISAF at different strain rates. The tensile tests were performed in accordance with ASTM D1623. The compression testing was performed in accordance to ASTM D1621. The testing assisted in performing an adequate simulation of the mechanical response of SAFKEG materials during accident scenarios. These mechanical properties are reported in Figures $11-18$.

The stress vs. strain curves measured for resin bonded cork in tension, compression and hydrostatic compression are shown in Figures $11-13$, respectively. The most notable observation of the cork is that it exhibits viscoelastic behavior. Specifically, the deformation of the material has an elastic component and viscous component. When the stress is removed the material will recover to the original shape over a time interval. The SARP stated that this recovery was $98 \%$. Load relation tests were conducted in compression and showed that and average $36 \%$ of the stress was relieved during a $30-\mathrm{sec}$ hold before unloading. In addition, the cork also shows a positive strain rate sensitivity at room temperature. This behavior was also observed in the hydrostatic compression tests, shown in Figure 13. Overall, the stress-strain properties measured in this study did not significantly differ from properties listed in the SARP.

The stress vs. strain curves measured for TISAF in tension and compression are shown in Figures 14 and 15, respectively. The foam is a mixture of gypsum and phenolic resin, which exhibits a very large, and widely varying, cell size. From Figure 14, the brittle nature of this material can be observed. The material exhibited very limited strain rate sensitivity. The tensile specimens failed without any appreciable nonlinear elasticity. In compression, material behaves in a similar fashion. The initial potion of the curve is linear until failure. Subsequent deformation occurs by successive loading and crushing events until complete "powdering" of the material. In Figure 16, a picture of a compression specimen after a compression test illustrates its brittle behavior. The behavior is significantly different to the properties exhibited in the SARP (Figure 10).

In order to determine the effect of stress state on deformation stress, the sample was compressed in a tri-axial compression fixture which was able to preload samples to constant loads in 2 orthogonal directions ( $\sigma 1$ and $\sigma 2)$ and measure breaking strength in the third $(\sigma 3)$. Plotting $\sigma 1$ and $\sigma 3$ together enables the determination of the yield surface using Mohr's circle. In Figure 17 the three curves that bound all other tensile or compression data are shown. When these curves are plotted using Mohr's circle a tangent line can be used to estimate the breaking strength at different loading conditions. In Figure 18, the $\sigma 1$ and $\sigma 3$ values of stress are plotted as intersection points to the $\mathrm{X}$-axis. A circle is used to plot the relationship between $\mathrm{X}$ and $\mathrm{Y}$. In this figure, a least squares fit of the tangent points was produced and the equation for the line is shown. Since the material is so brittle and the stress-state is compressive, the tensile curve was neglected and a yield surface was estimated with the two compression tests. This data was used as input to the stuructrual impact analysis of the SAFKEG in KAMS under accident conditions.

\subsection{THERMAL PROPERTIES}

Thermo-gravimetric analysis was used to measure indicate whether aging at elevated temperatures would lead to a change in properties during interim storage. The SARP states that the cork and TISAF are unaffected during aging at temperature up to $180 \mathrm{C}$ and $140 \mathrm{C}$, respectively. A weight loss of approximately $7 \%$ was noted for both materials (attributed to drying of entrained water). Figures 19 and 20 are weight loss vs. temperature plots of cork and 
TISAF, respectively. Initially, a small amount of weight loss (presumably from absorbed water) appears to occur during hold and heating up to $140 \mathrm{C}$. Samples of cork and foam have been observed to lose up to 6.5 and $3.5 \mathrm{wt}$. \%, respectively, upon heating to $248^{\circ} \mathrm{F}\left(120^{\circ} \mathrm{C}\right)$. So the weight loss, previously reported in the SARP, is representative of the samples tested in the present study. After this initial adjustment, the weight stabilizes until $572^{\circ} \mathrm{F}\left(300^{\circ} \mathrm{C}\right)$ for cork and $752^{\circ} \mathrm{F}\left(400^{\circ} \mathrm{C}\right)$ for $\mathrm{TISAF}$. Above these respective temperatures, the majority of the sample is consumed. In the case of the cork, $100 \%$ of the sample $(80 \%$ flowing argon in air) is consumed before $932^{\circ} \mathrm{F}\left(500^{\circ} \mathrm{C}\right)$ is reached. In the case of TISAF, $55 \%$ of the weight is consumed before $1022^{\circ} \mathrm{F}\left(550^{\circ} \mathrm{C}\right)$. Beyond this temperature, the sample weight remains relatively constant up to $1472^{\circ} \mathrm{F}\left(800^{\circ} \mathrm{C}\right)$.

\subsection{DISCUSSION}

Ambient temperature mechanical properties of the TISAF and cork have been established. Tensile and compression data are shown in Table 1. The calculated temperatures (Table 2) during storage for these materials reach a maximum of $232^{\circ} \mathrm{F}\left(111^{\circ} \mathrm{C}\right)$ for the cork and $146^{\circ} \mathrm{F}$ $\left(63^{\circ} \mathrm{C}\right)$ for TISAF. $\left.{ }^{12}\right)$ These temperatures are high enough to cause depletion in water or loss of volatile organic compounds. This could have an impact of mechanical and physical properties. The long term effects of temperature will be established during the surveillance program in KAMS, which should include sampling of the TISAF and cork and performing tests to determine physical and mechanical properties and examination for moisture effects. The development of specific surveillance activities for these materials is beyond the scope of this report.

A study has already been initiated by Sandia to determine thermal aging effects on mechanical properties of polyurethane foam used in multiple weapons systems. ${ }^{13)}$ In this case, the foams are used for volume fillers, electrical isolation and shock and vibration absorbers. The specified foam for the Sandia testing is BKC44402 (available from Honeywell Federal Manufacturing and Technologies). The density of this foam is $0.1 \mathrm{~g} / \mathrm{cm}^{3}$, which is slightly less than the TISAF $(0.4$ $\mathrm{g} / \mathrm{cm}^{3}$ ). The Honeywell foam does not contain a filler material while the TISAF uses gypsum. The aging time intervals for this study are 1 week, 3 months, 7 months, 1 year and every year thereafter until the final 4 year period is reached. Aging data after 1 year at ambient temperature, $60^{\circ} \mathrm{C}$ and $80^{\circ} \mathrm{C}$ are summarized as follows:

- Impact tests for specimens aged at $60^{\circ} \mathrm{C}$ and $80^{\circ} \mathrm{C}$ revealed a drop in energy absorption after 7 months of aging.

- Specimens aged at ambient temperature showed signs of decreased energy absorption after 1 year.

- Spallation was observed while foam is compressed during the impact test

- Conventional tensile and compression behavior was unaffected through 1 year of aging at temperatures up to $80^{\circ} \mathrm{C}$.

- Initial mass increase after exposure to room temperature, most likely due to moisture absorption.

- Mass losses (less than $1.7 \%$ ) after exposure to $60^{\circ} \mathrm{C}$ and $80^{\circ} \mathrm{C}$ for 1 year, suggested to be result of moisture and surfactant losses.

Another study on natural cork showed that the viscoelastic behavior of cork changed above $140^{\circ} \mathrm{F}\left(60^{\circ} \mathrm{C}\right) .{ }^{14)}$ Specifically, increases in the storage modulus and decreases in the relaxation processes were observed during heating or aging at or above this temperature. This diminishes the damping capabilities of cork. 
It is not known whether TISAF will perform in a similar fashion to the polyurethane foam from the SANDIA study. Diminished damping capacity of cork would adversely impact its performance in structural analyses.

\subsection{CONCLUSION AND RECOMMENDATIONS}

The results of the evaluation of the aging assessment of the resin-bonded cork and the TISAF materials of the SAFKEG 3940A package support its use for interim storage in KAMS for a period of $10+$ years, while maintaining full containment and handleability of the package,. The results were based on limited baseline and aging data. This conclusion is predicated on the surveillance of the materials to verify that degradation, significant to the performance of the 3940A package to provide containment and handleability, is not occurring.

\subsection{QUALITY ASSURANCE}

The preparation of this technical work and its documentation were performed as specified in the WSRC E7 Manual, procedure 3.60. Laboratory notebooks for the materials testing were maintained in accordance with SRTC Procedure L1, 7.16, Rev. 2. Internal technical review of this report is governed by the WSRC E7 Manual, procedure 2.40.

\subsection{REFERENCES}

1) LAUR-01-2081, Rev. 1 Draft, Safety Analysis Report for SAFKEG 3940A, Los Alamos National Laboratory, September 27, 2002.

2) DOE Standard, DOE-STD-3013-2000, Stabilization, Packaging, and Storage of Plutonium-Bearing Materials, U.S. Department of Energy, September 2000.

3) R. A. Vaughan, CTR 2001/12 Issue C, Summary of Physical Properties and Compositions of TISAF, September 27, 2002 in LAUR-01-2081, Rev. 1 Draft, Safety Analysis Report for SAFKEG 3940A, Los Alamos National Laboratory, September 27, 2002).

4) R. A. Vaughan, E-mail to P. R. Vormelker, Subject: TISAF in SAFKEG 394-A, April 8, 2003.

5) W. G. Ashbaugh, "Corrosion Under Thermal Insulation," Metals Handbook ${ }^{\circledR}$ Ninth Edition Volume 13 Corrosion, ASM International (1987), pp. 1144-1147.

6) D. M. Street, R. F. Smith, T. Fitzsimmons, and D. Willoughby, A Total Engineering Approach to the Problem of Corrosion of Steel Insulation, Symposium Proceedings Corrosion Under Wet Thermal Insulation: New Techniques for Solving Old Problems, National Association for Corrosion Engineers, 1990.

7) T. L. Smith, J. D. Carlson, and T. L. Walzak, Steel Deck Corrosion Associated with Phenolic Roof Insulation: Problem Causes, Prevention, Damage Assessment and Corrective Action, Proceedings of the 10th Conference on Roofing Technology, Gaithersburg, Md, National Roofing Contractors Association, April 22-23, 1993. 
8) ASTM D 2842, Standard Test Method for Water Absorption of Rigid Cellular Plastics, ASTM International (2001).

9) P. R. Vormelker, WSRC-TR-2003-0195, Internal/External Corrosion Analysis of the SAFKEG 3940A Package in KAMS, Westinghouse Savannah River Company, May 2003.

10) LA-UR-93-4509, SAFKEG-SARP-01, Rev. 1, Safety Analysis Report for Packagings for SAFKEG 2863B, Los Alamos National Laboratory, June 1992.

11) D. G. Kolman, LA-UR-98-5762 Revision 1, An Assessment of the Corrosion, Stress Corrosion, Cracking, and Embrittlement of 3013 Storage Containers, Los Alamos National Laboratory, 1999.

12) N. K. Gupta, "Thermal Analysis of the SAFKEG Package for KAMS Project," Calculation M-CLC-K-006600 (U), Westinghouse Savannah River Company, May 27,2003.

13) S. H. Goods and L. L. Whinnery, SAND2000-8245, The Effect of Thermal Aging on the Mechanical Properties of a Stockpile Polyurethane Foam, Sandia National Laboratories, June 2000.

14) J. F. Mano, "The viscoelastic properties of cork," Journal of Materials Science, Vol. 37, pp. 257-263 (2002) 


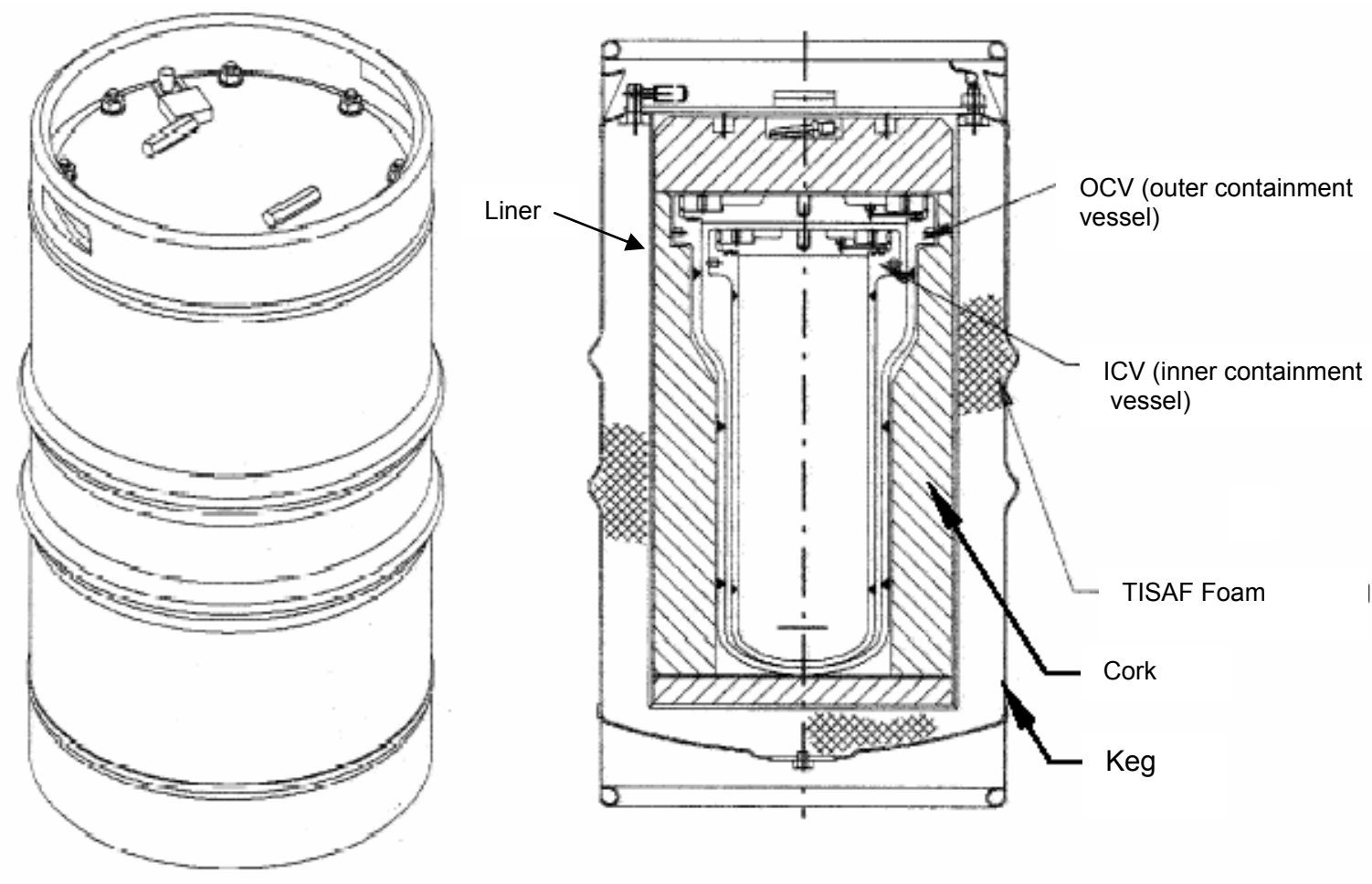

Figure 1. SAFKEG 3940A shipping package showing location of the keg, TISAF foam, cork, outer containment vessel (OCV), and the inner containment vessel (ICV). The 3013 vessels will be inserted into the ICV of the SAFKEG. The SAKEG is approximately 40 inches high. 


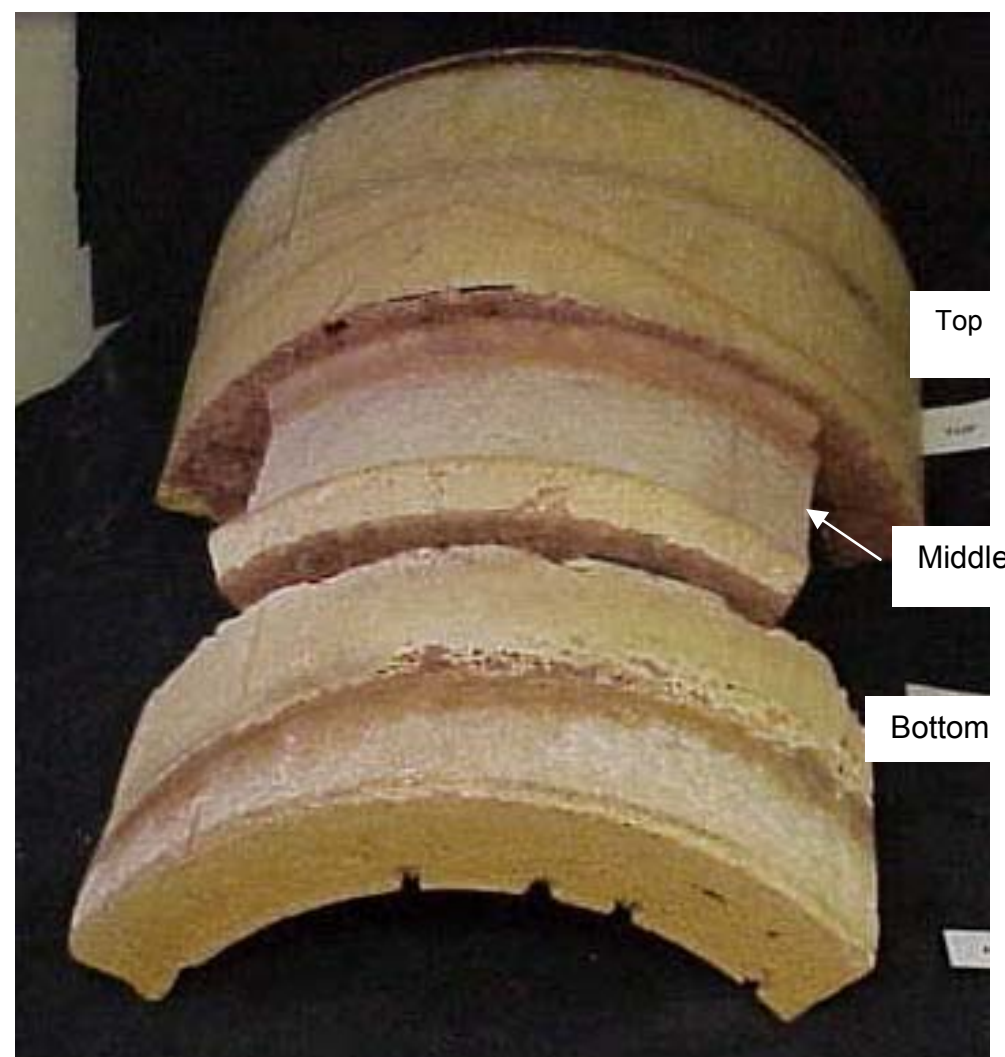

Digital Image

Figure 2. Exterior sections (top, middle, and bottom) of TISAF taken from a SAFKEG package. Surface is rough in a few places in the bottom section. The thickness is slightly more than $1 \frac{3}{4}$ inches. Note there is no surface coating on the TISAF. This is probably not typical of the SAFKEG 3940A package. 


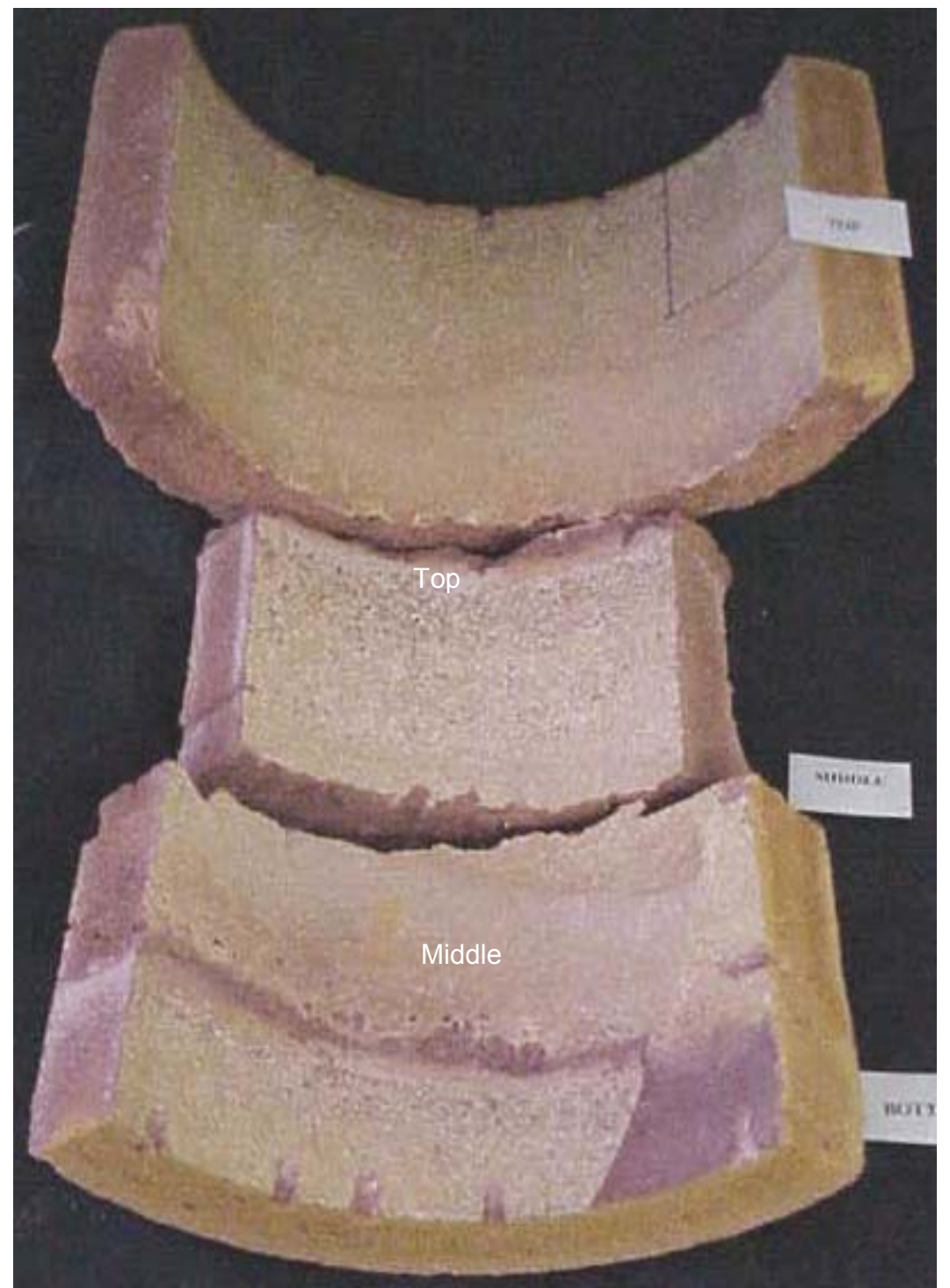

Digital Image

Figure 3. Exterior sections (top, middle, and bottom) of TISAF taken from a SAFKEG package. Surface is rough in a few places. Note there is no surface coating on the TISAF. This may not be typical of the SAFKEG 3940A package. 


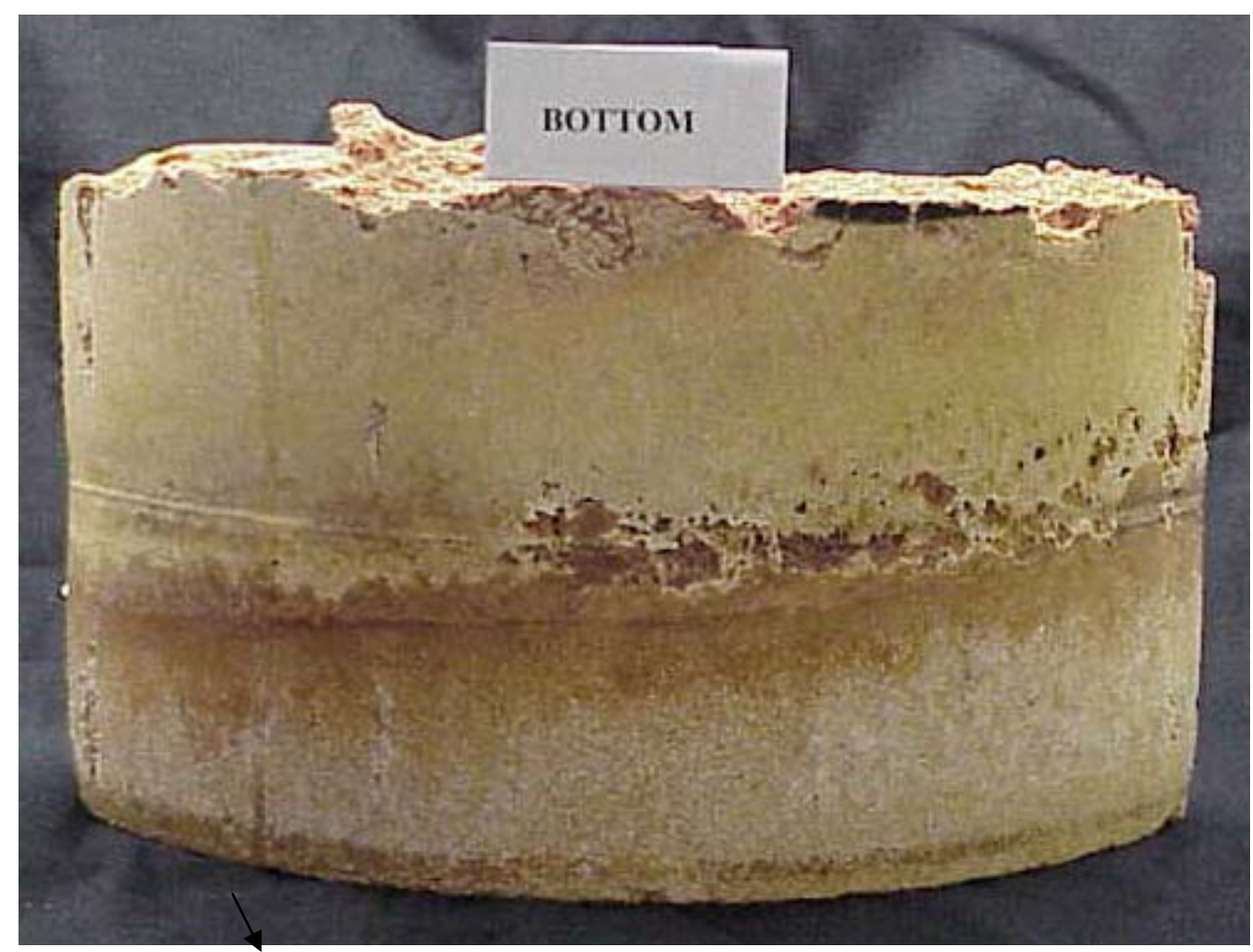

Digital Image

Figure 4. Outer surface of middle section of TISAF revealing surface problems in middle. The arrow, to the left, shows the location of the parting line between the two separate pours of the foam during filler of the cavity. 


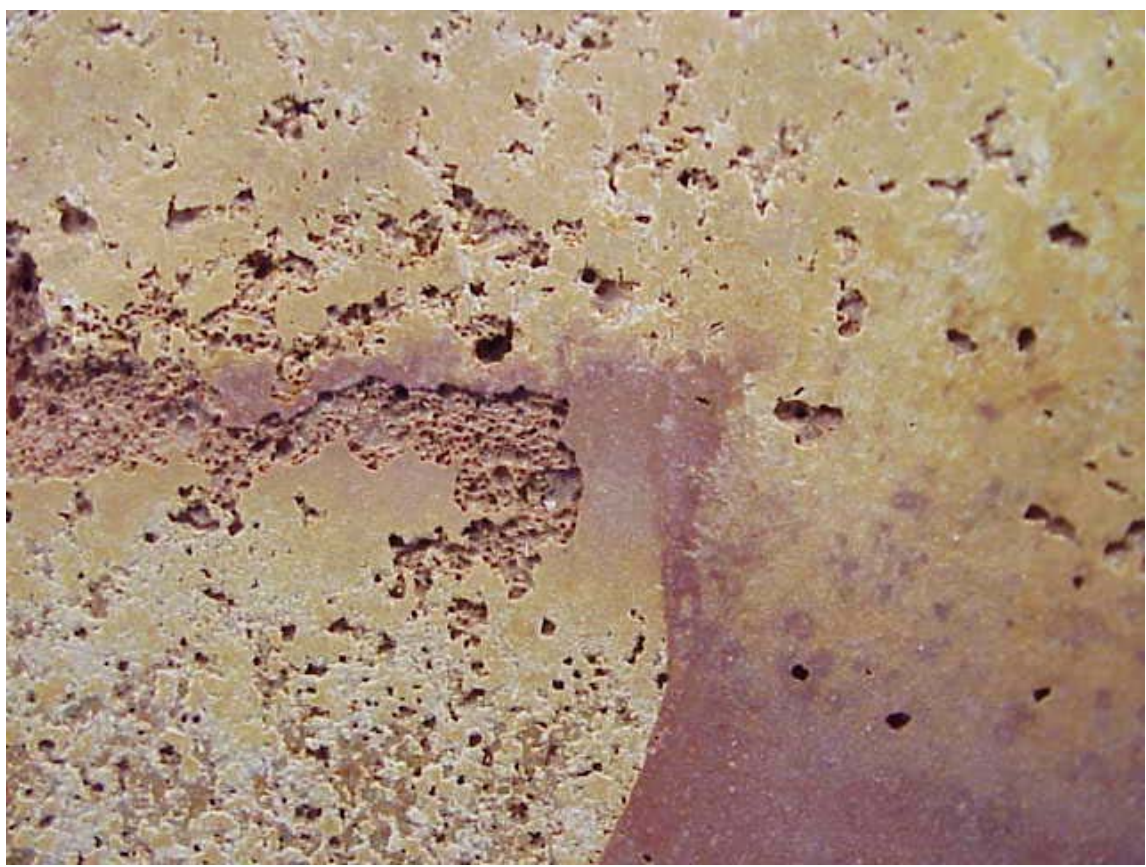

Digital Image

Figure 5. Inner surface of bottom section of TISAF from Figure 3 revealing exposed porosity on surface.

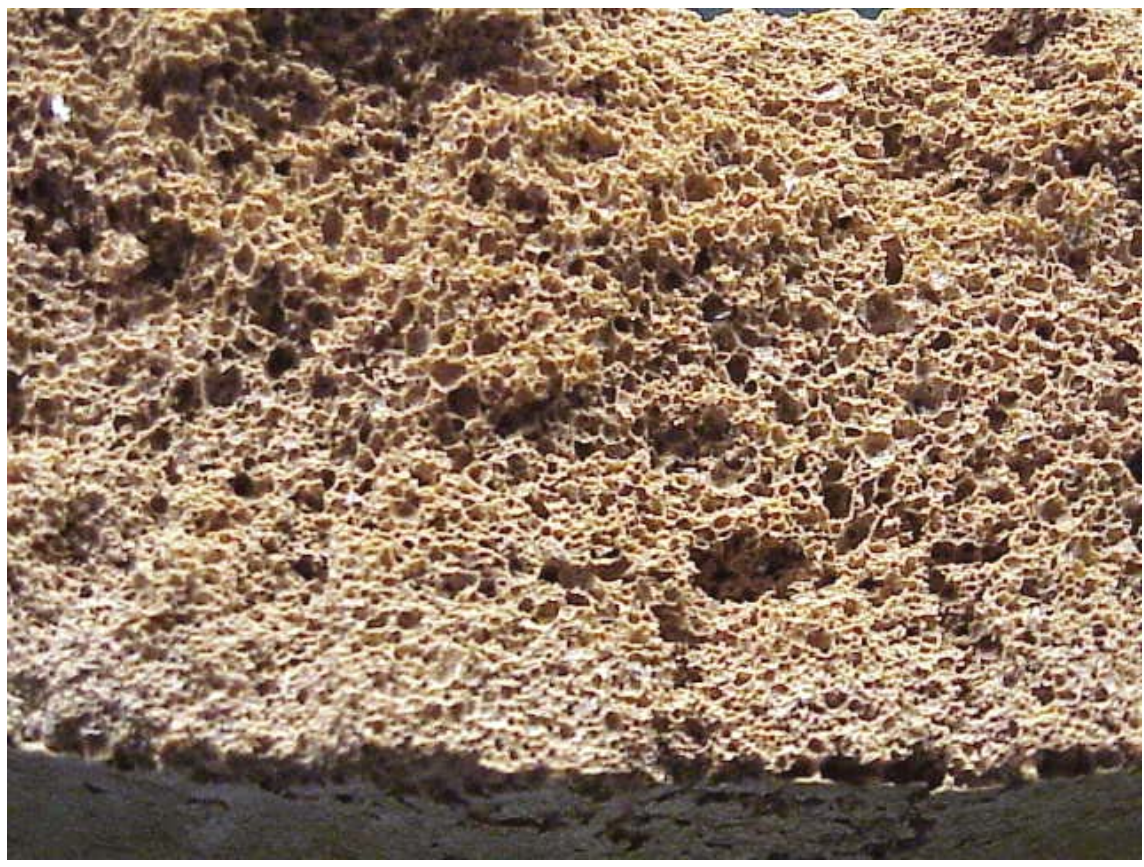

Digital Image

Figure 6. Photo of broken section of TISAF revealing wide range of cell sizes. 


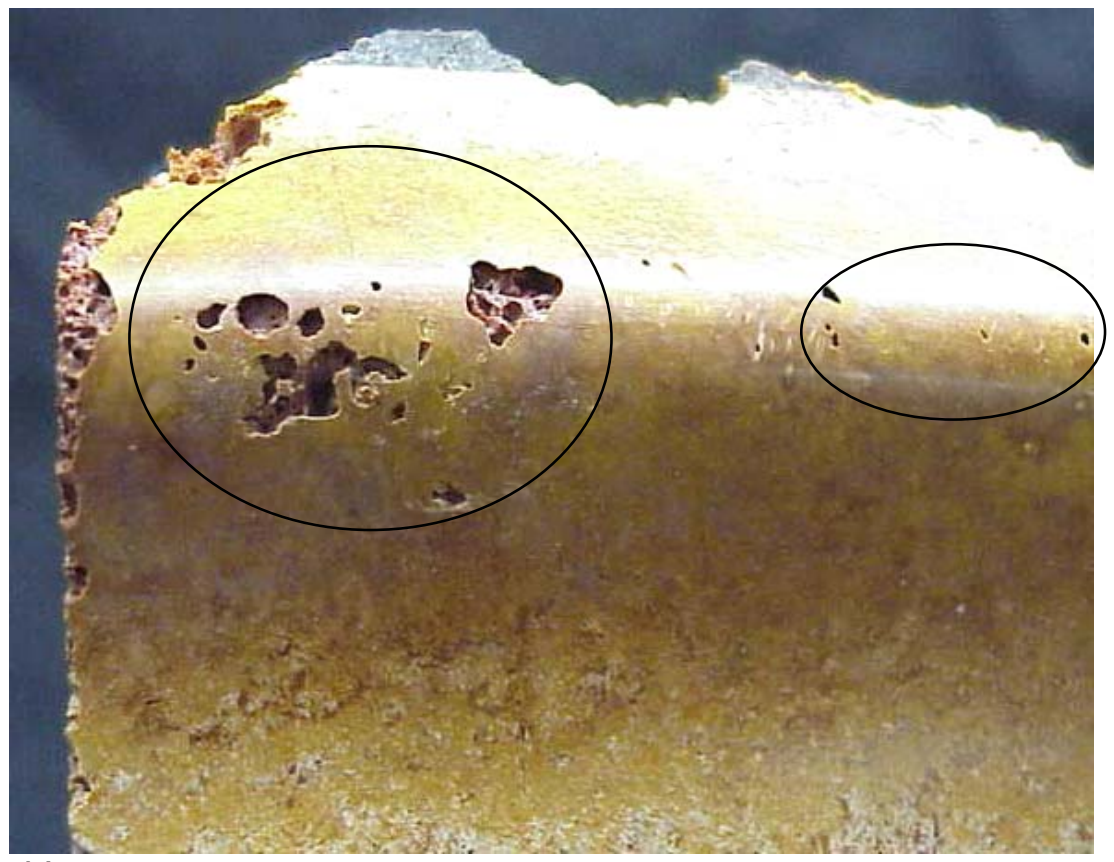

Digital Image

Figure 7. Circled areas in Image reveals porosity on the ridge formed by the outer keg.

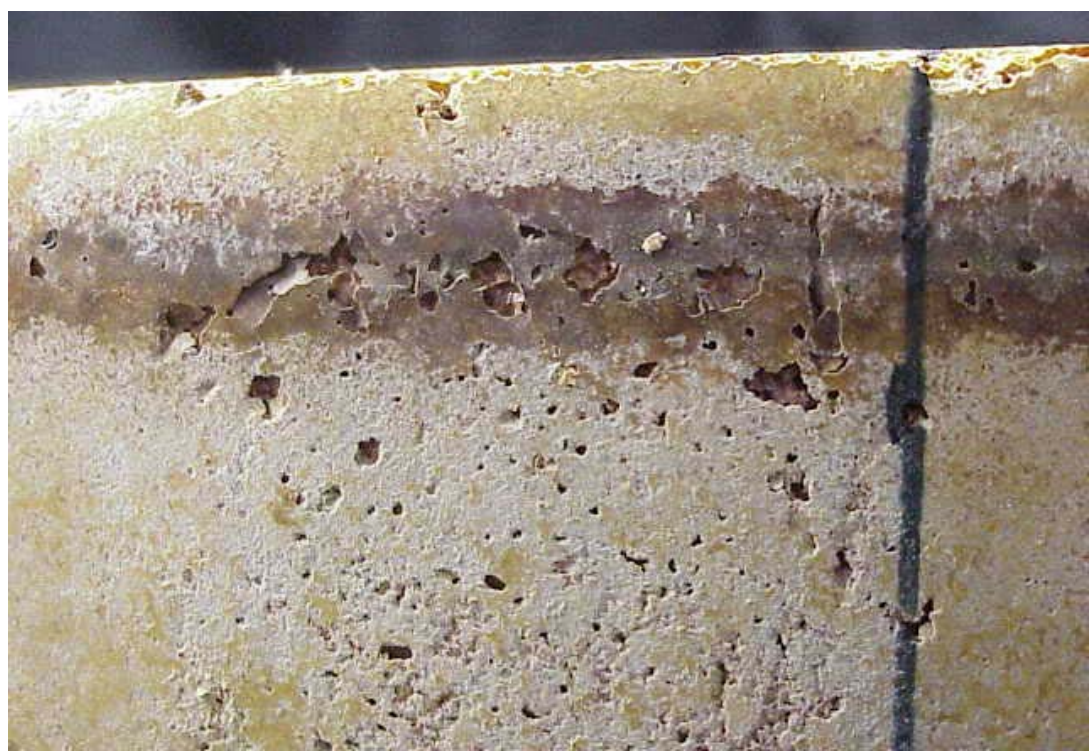

Digital Image

Figure 8. In top TISAF section, near the top surface, porosity is visible. 
Uniaxial Compression Test Data of Resin Bonded Cork (SARP)

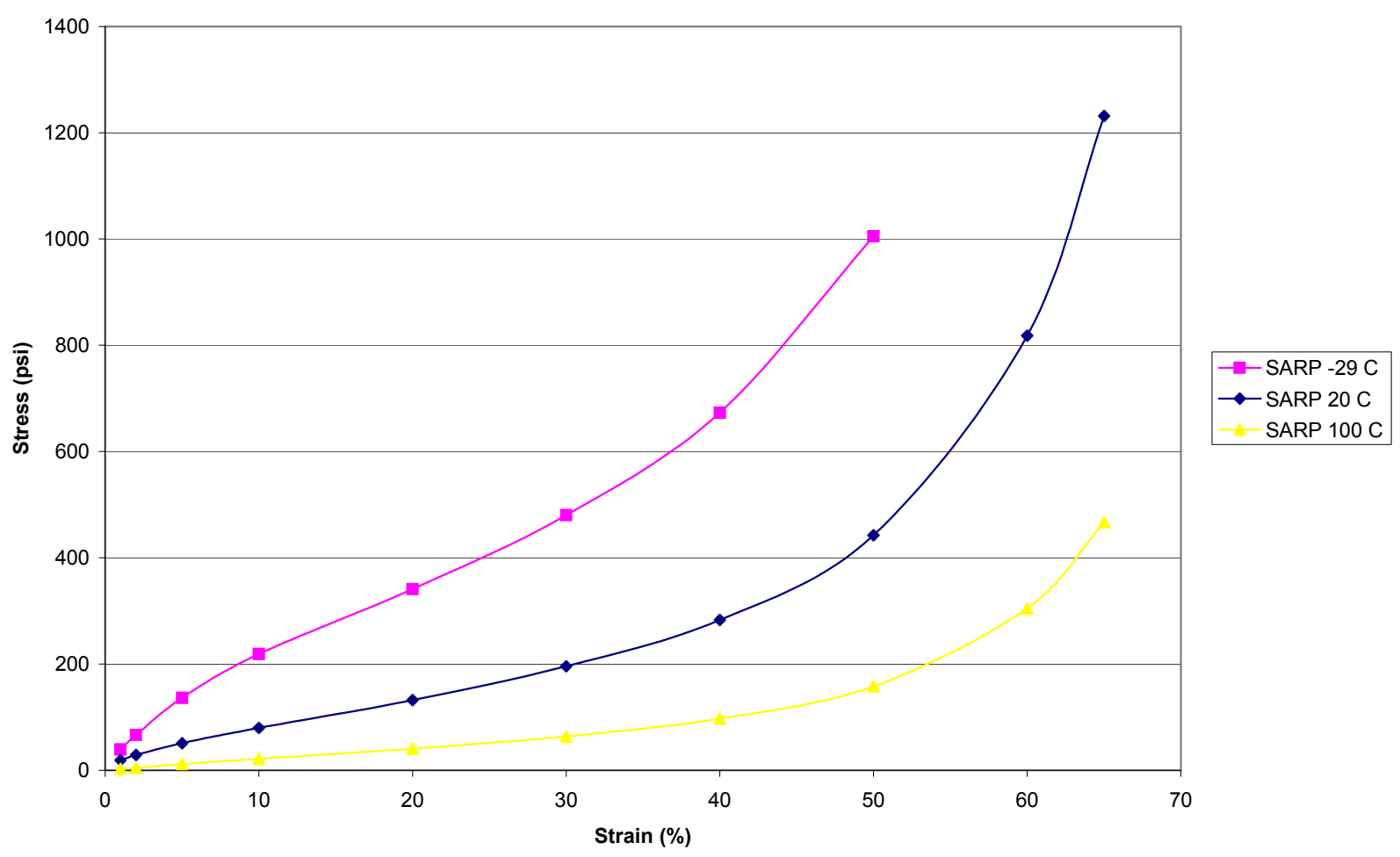

Figure 9. Room Temperature Compression Test Data for Resin Bonded Cork ${ }^{11}$.

Uniaxial Compression Test Data of TISAF (SARP)

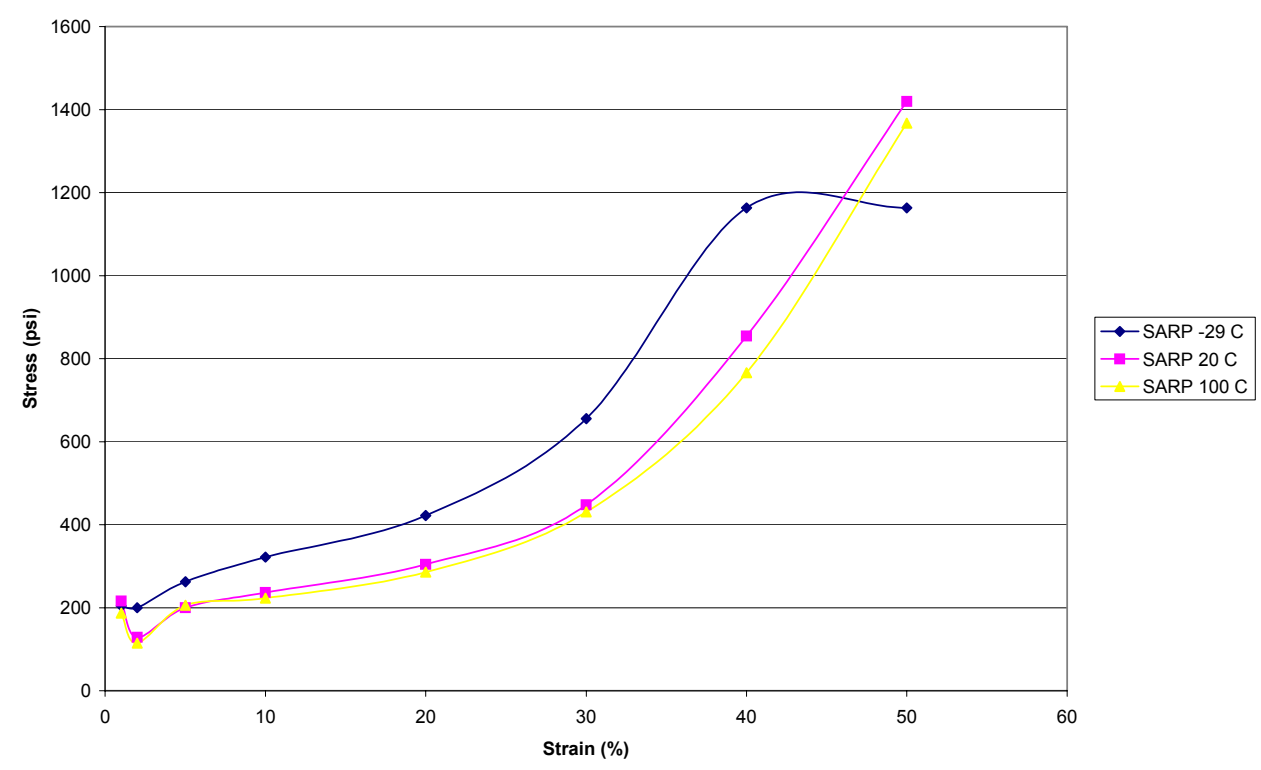

Figure 10. Room Temperature Compression Test Data for $\operatorname{TISAF}^{11}$. 


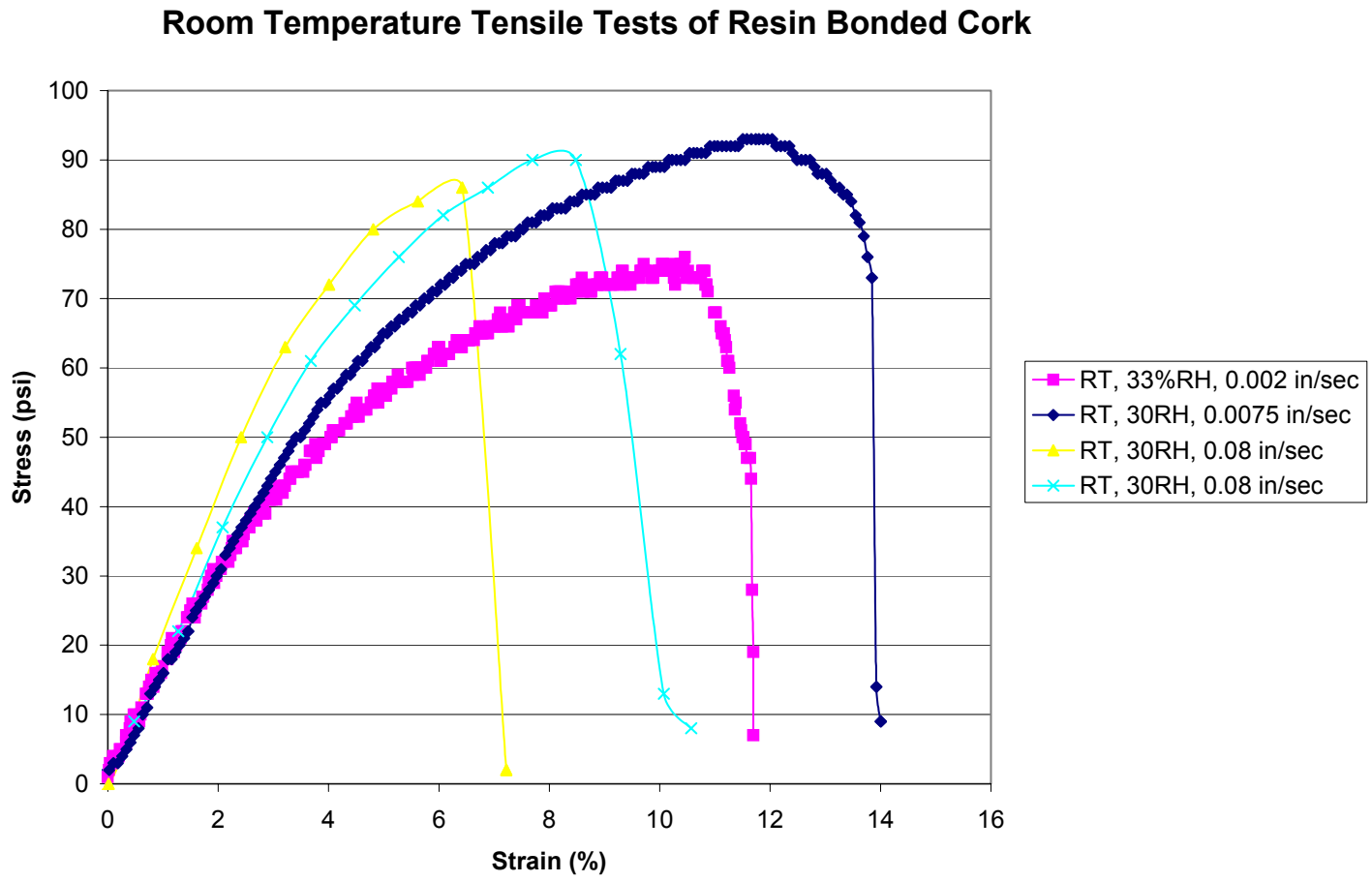

Figure 11. Room Temperature Tensile Test Data of Resin Bonded Cork.

Room Temperature Uniaxial Compression Testing of Resin Bonded Cork
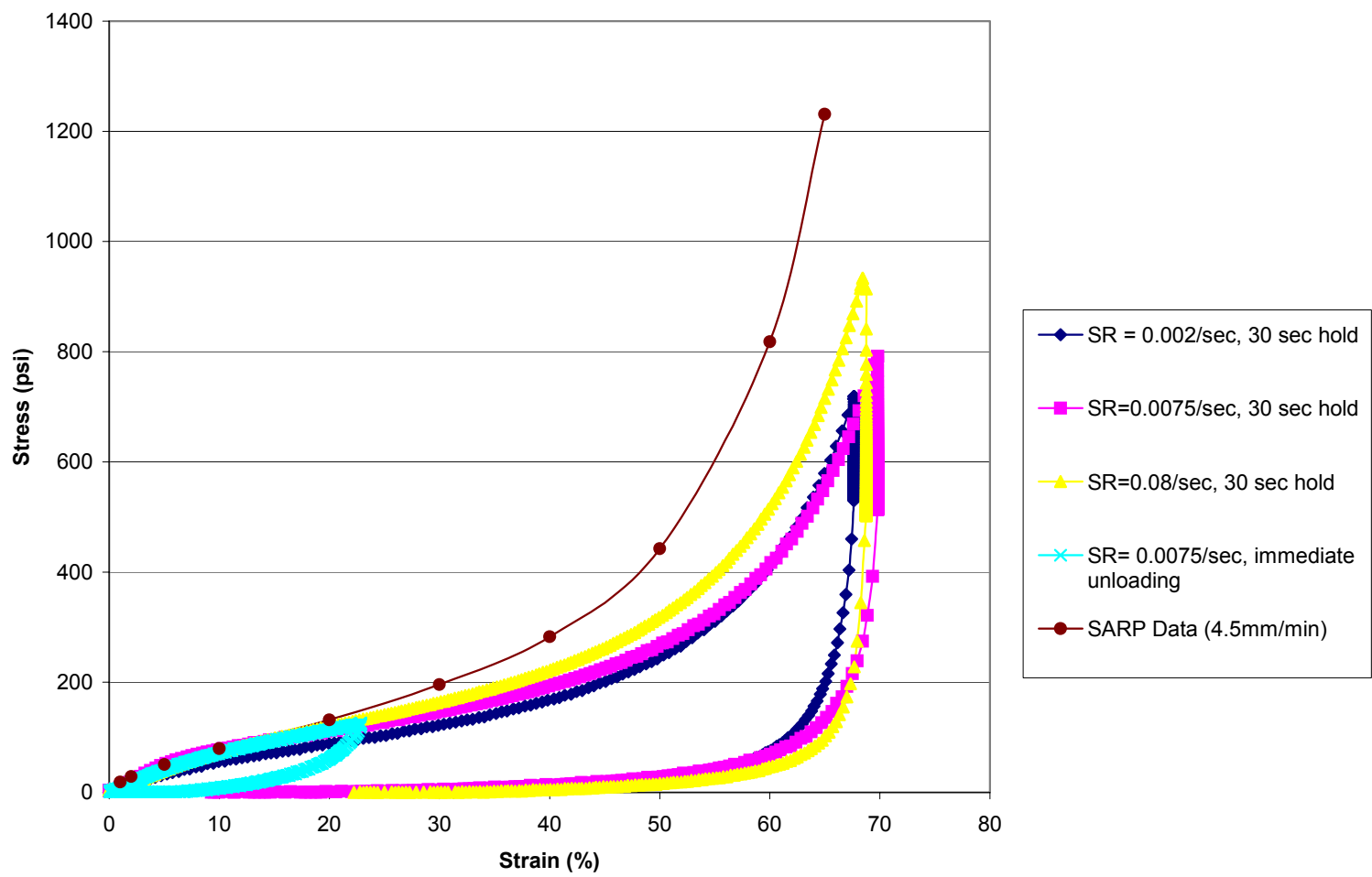

Figure 12. Room Temperature Uni-axial Compression Data of Resin Bonded Cork. 


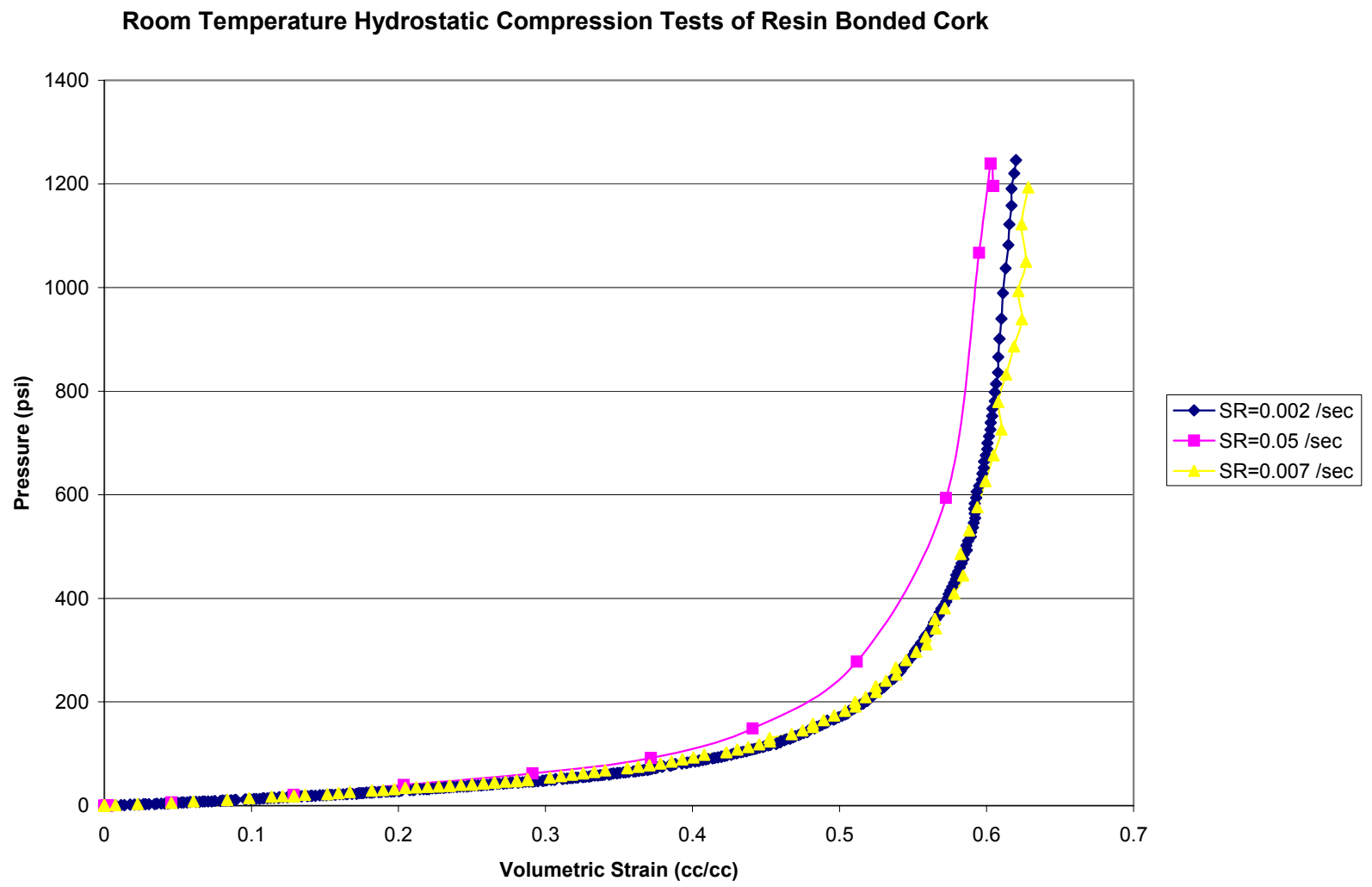

Figure 13. Room Temperature Hydrostatic Compression Data for Resin Bonded Cork

Room Temperature Tensile Tests of TISAF

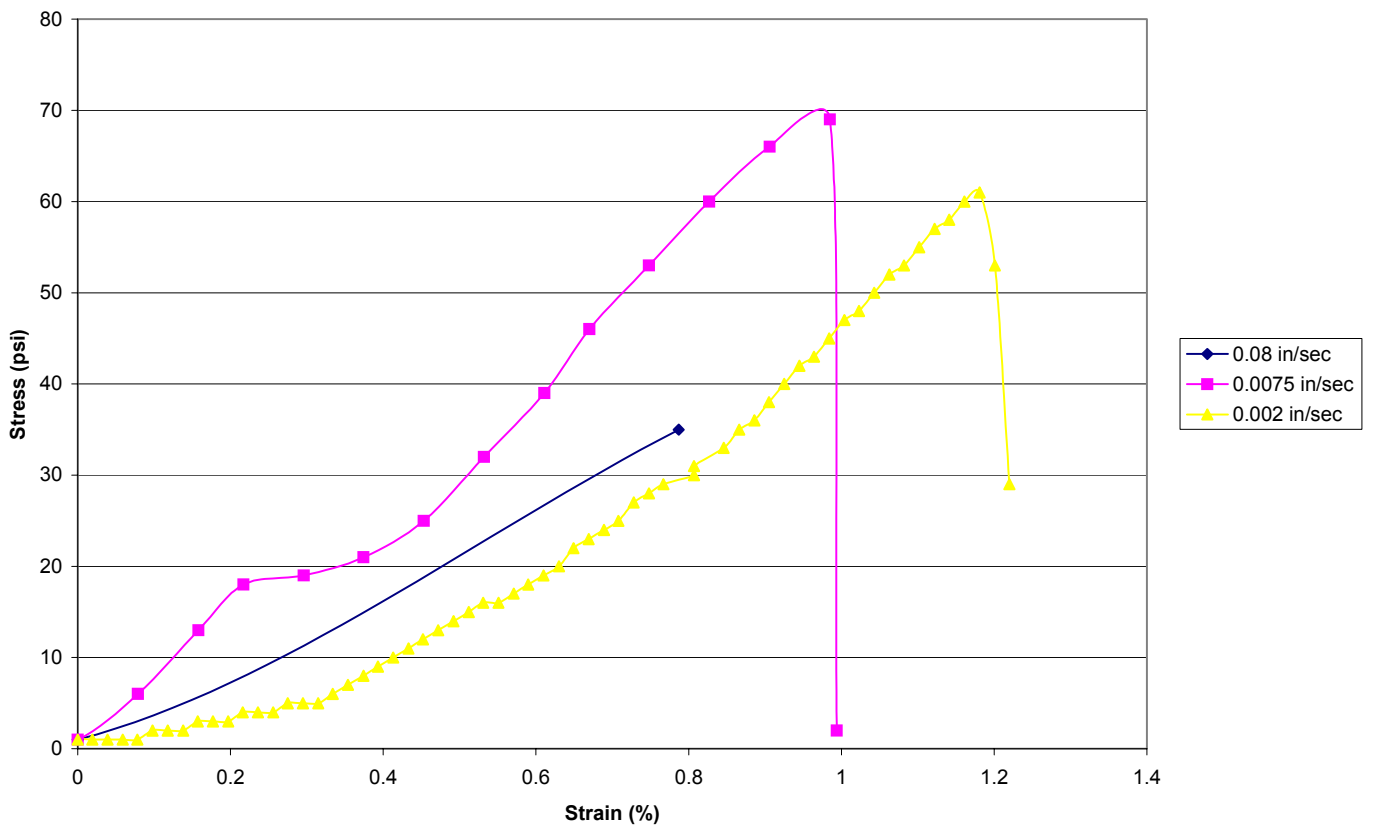

Figure 14. Room Temperature Tensile Test Data of TISAF. 


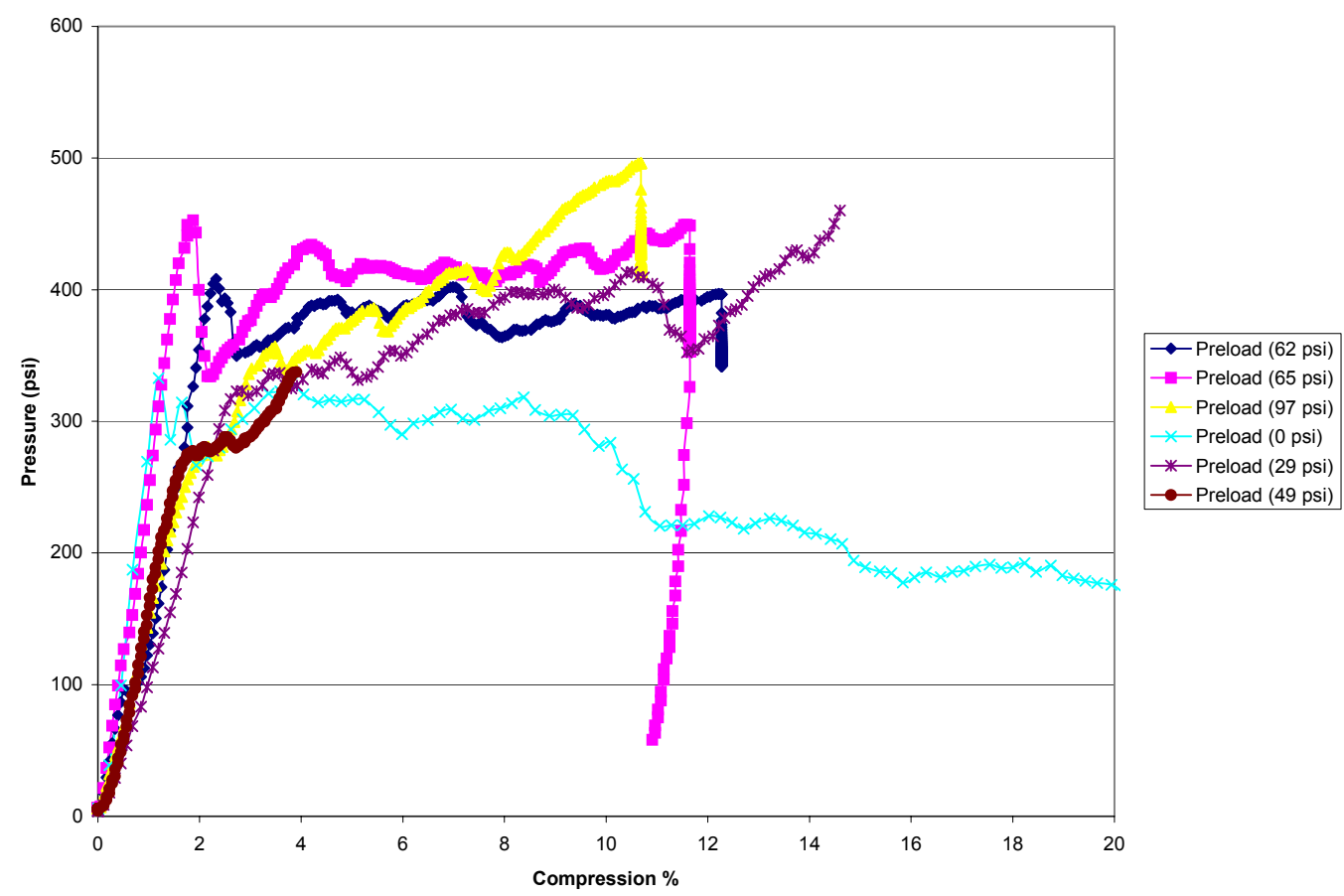

Figure 15. Room Temperature Test Data for TISAF in Compression, Tension and Tri-axial Compression.

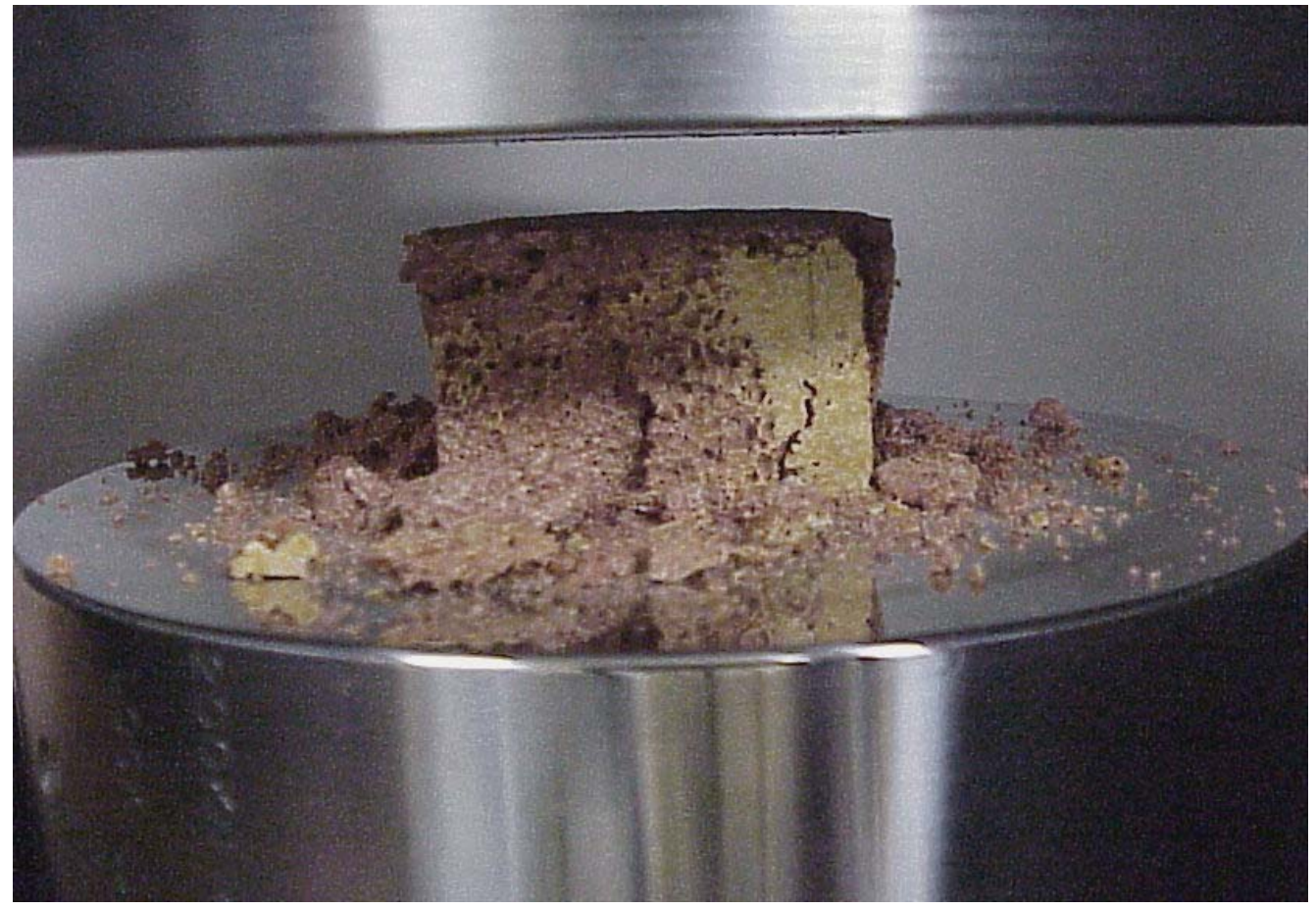

Figure 16. Room Temperature Compression Test of TISAF. 


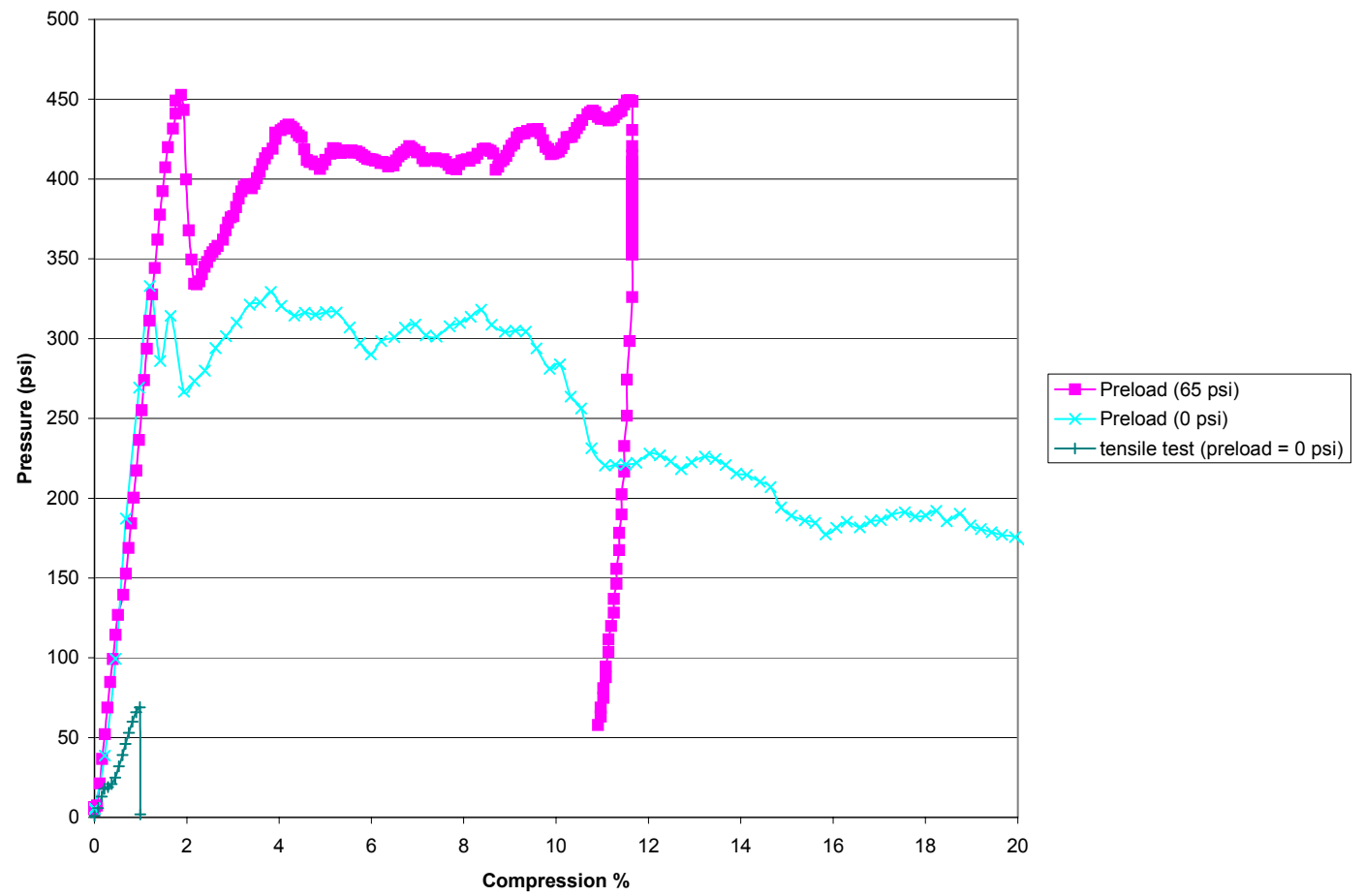

Figure 17. Selected Stress Strain Curves used for the Mohr's Circle representation of Fracture Stress vs. Shear Stress for TISAF.

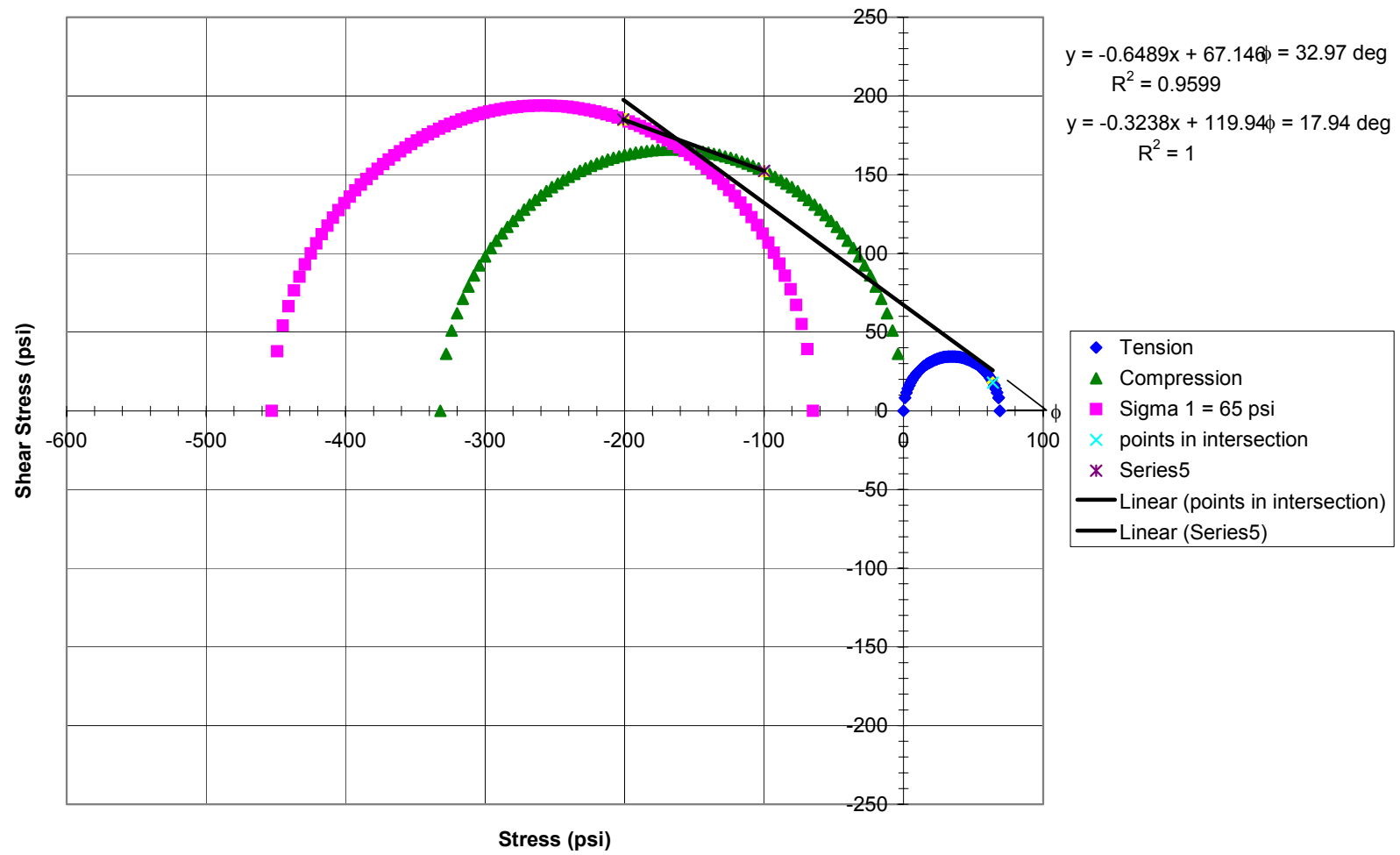

Figure 18. Mohr's Circle representation of Fracture Stress vs. Shear Stress for TISAF. 


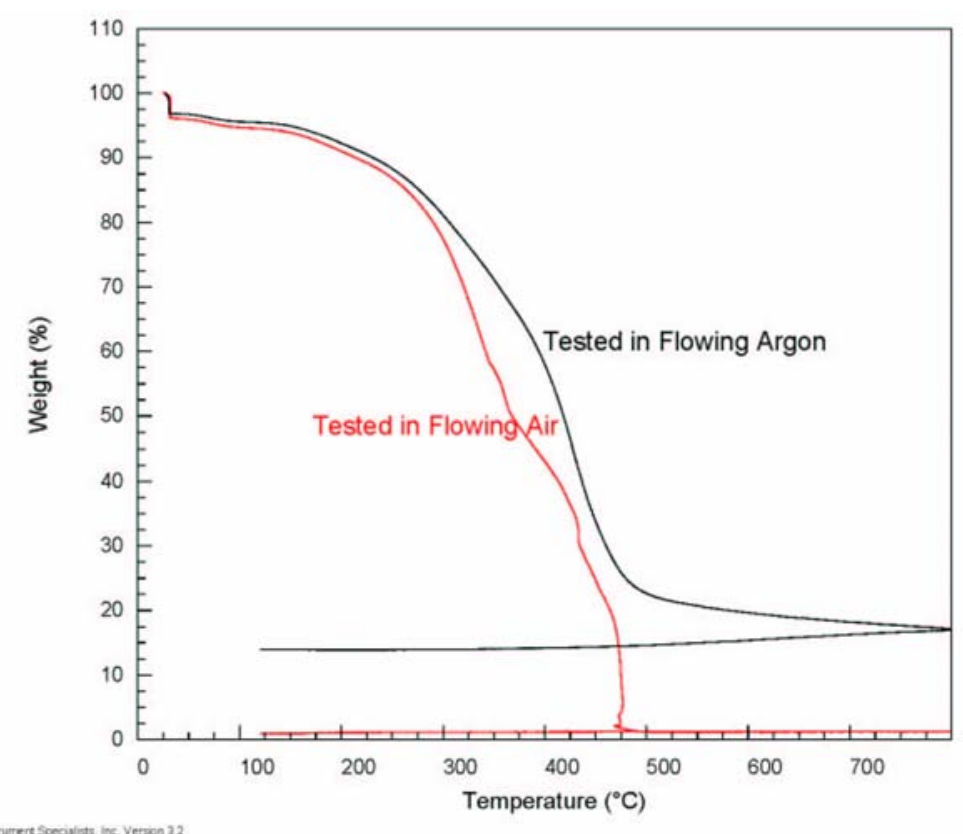

Figure 19. Weight loss from TGA Analysis of Resin Bonded Cork in Flowing Argon and Air.

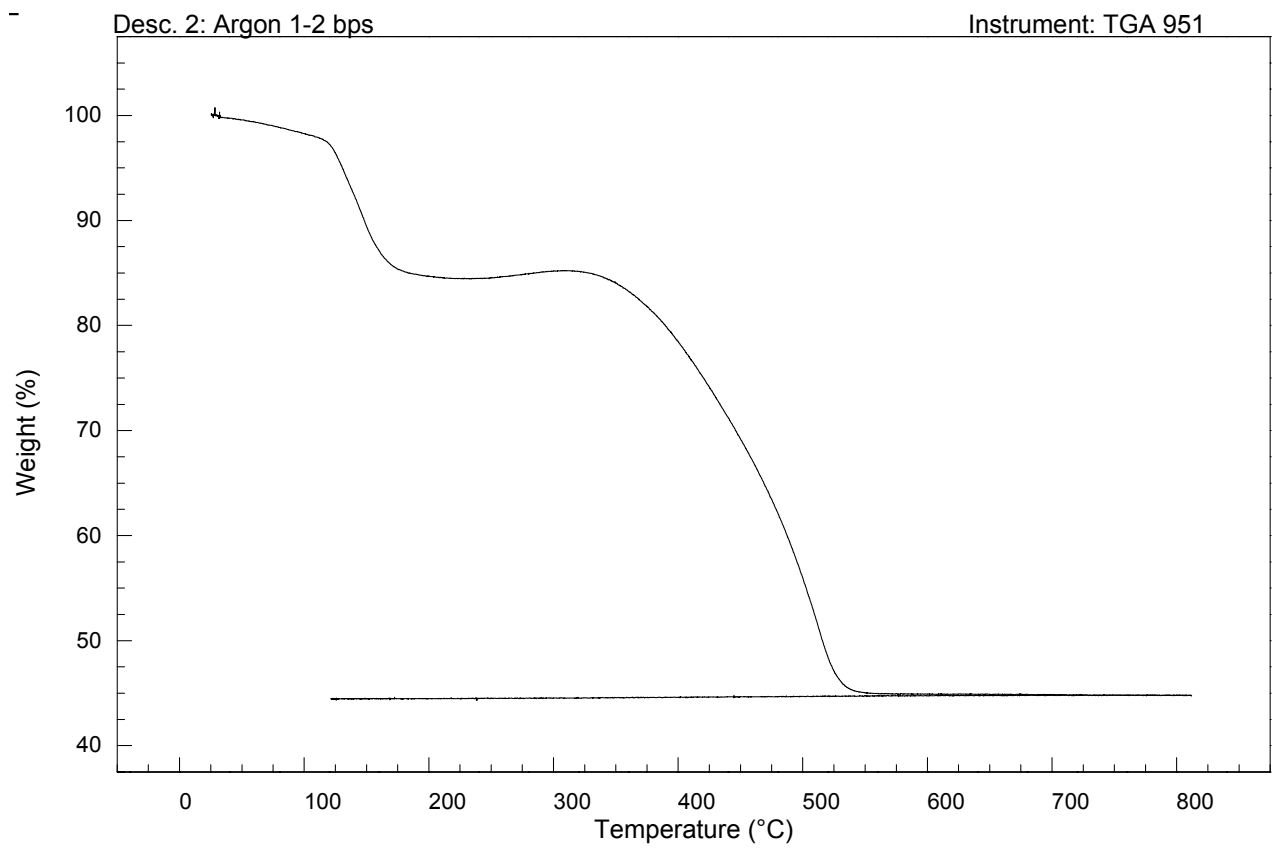

Figure 20. Weight loss from TGA Analysis of TISAF in Flowing Argon. 